\title{
Sensitivity Comparison of Nested RT-PCR with Immunofluorescence for Diagnosis of Rabies
}

\author{
K Bansal ${ }^{1}$, C K Singh 2 , M Dandale ${ }^{3}$, B S Sandhu ${ }^{4}$, N K Sood ${ }^{5}$ \\ 1,2,3,4,5 Department of Veterinary Pathology, College of Veterinary Sciences, Guru Angad Dev Veterinary and \\ Animal Sciences University, Ludhiana-141004, India
}

\begin{abstract}
In the present study sensitivity of diagnosis of rabies with Nested RT-PCR was compared with Immunofluorescence on 20 brain samples. RNA extraction was done using Qiazol method. Synthesis of cDNA was done using rabies specific primers. Nested set of primers were used to amplify highly conserved $762 \mathrm{bp}$ nucleoprotein gene region. Nested RT-PCR was able to diagnose rabies viral RNA in 12 out of 13 Immunofluorescence positive cases. Sensitivity of Nested RT-PCR was found to be $92.31 \%$ when compared with Immunofluorescence. Thus, the present study concluded that Nested RT-PCR can be served as an additional tool for confirmatory diagnosis of rabies
\end{abstract}

Keywords: Brain, Diagnosis, Immunofluorescence, Nested RT-PCR, Rabies, Sensitivity

\section{INTRODUCTION}

India has the dubious distinction among the rabies enzootic Asian countries in reporting more than 20,000 human rabies deaths annually [1]. Although rabies virus adapts to different hosts for persistence [2], dogs continue to play a major role in maintenance and transmission of the disease [3]. The fluorescent antibody test (FAT) is the standard and most frequently primary used method of rabies diagnosis [4]. FAT gives reliable results on fresh specimens within a few hours in $95-99 \%$ of cases. The sensitivity of the FAT is dependent on the quality of the specimen, conjugate, equipment and the skills of the diagnostic staff. Confirmatory mice inoculation test (MIT) requires 21-28 days, facilities for experimental animals, and is labour intensive. Thus, MIT has been replaced by the rabies tissue culture infection test on cell cultures (RTCIT). However, it may be performed only in well equipped laboratories with skilled staff. Further, RTCIT and MIT are both directed at the detection of only live virus. Since the speed of obtaining results is the most important criterion in the diagnosis of rabies, [5] recommend the RT-PCR as a supplementary method. The present study was, therefore, undertaken to compare the sensitivity of Nested RT-PCR with Immunofluorescence, for making reliable confirmatory diagnosis.

\section{MATERIALS AND METHODS}

Collection of brain samples

In the present study, brain tissue samples were collected from 20 cases ( 7 buffaloes, 5 cattle and 8 dogs). Molecular assay viz. Nested RT-PCR and conventional assay viz. Immunofluorescence was applied for comparing the sensitivity diagnosis of rabies virus from brain samples.

\subsection{RNA extraction and cDNA synthesis}

Total RNA from brain samples, positive and negative controls was extracted using Qiazol (Qiagen, USA) according to the manufacturer's instructions. The RNA was subjected to cDNA synthesis using a primer RabN1 (30 pmol/ $\mu \mathrm{l})$ and subjected to $65^{\circ} \mathrm{C}$ for $10 \mathrm{~min}$ and was later snap cooled on ice and briefly spun down.

cDNA synthesis was done using high-capacity cDNA reverse transcription kit (Applied Biosystems, USA). Reverse transcriptase (Applied Biosystems, USA) mix was prepared and subjected to conditions $25^{\circ} \mathrm{C}$ for $10 \mathrm{~min}, 37^{\circ} \mathrm{C}$ for $2 \mathrm{~h}, 85^{\circ} \mathrm{C}$ for $5 \mathrm{~min}$ and chilling on ice for $5 \mathrm{~min}$ in a thermal cycler (Eppendorf). RNA and cDNA concentration was measured using Nano Drop Spectrophotometer (Nanodrop Technologies, CA) in ng/ $\mu \mathrm{l}$ and quality was checked as a ratio of OD 260/280.

\subsection{Nested RT-PCR}

The procedure used for the nested RT-PCR based on N (Nucleoprotein) gene was that used earlier [6, $7,8]$ with minor modifications. Briefly, $12 \mu \mathrm{l}$ of cDNA was subjected to a first round amplification using RabN1 and RabN5 primers ( $30 \mathrm{pmol} / \mu \mathrm{l})$, dNTP's and Taq DNA polymerase for $95^{\circ} \mathrm{C}$ for 2 min followed by 35 cycles of $95^{\circ} \mathrm{C}$ for $1 \mathrm{~min}, 55^{\circ} \mathrm{C}$ for $1 \mathrm{~min}, 72^{\circ} \mathrm{C}$ for $1 \mathrm{~min} 30 \mathrm{~s}$ and a final extension step at $72^{\circ} \mathrm{C}$ for $5 \mathrm{~min}$. For the second round, $5 \mu \mathrm{l}$ of first round PCR product was amplified using Rab Nfor and Rab Nrev and subjected to thermo cycling conditions as first PCR except annealing at $55^{\circ} \mathrm{C}$ and extension for $1 \mathrm{~min}$. The amplified PCR 
Sensitivity Comparison of Nested RT-PCR with Immunofluorescence for Diagnosis of Rabies

products were loaded on agarose gels along with positive control, negative control and DNA ladder (100 base pair plus, Fermentas). The agarose gels were visualized under Geldoc (Bio-Rad).

\section{$2.4 \quad$ Immunofluorescence}

The Immunofluorescence was applied as gold standard diagnostic test by using the standard procedure as described by [9]. Duplicate impression smears of $1 \mathrm{~cm}$ diameter on either ends of the labelled slides were prepared from cerebellum in case of large animals and from hippocampus in case of dogs. Control positive slides from known rabies positive case and control negative slide from normal, uninfected and unvaccinated animal was also prepared along the smear. The slides were examined using an AHBT3 - RFC reflected light fluorescence attachment (Olympus, Japan).

2.5 Sensitivity comparison of nested RT-PCR with Immunofluorescence for detection of rabies virus

The sensitivity of nested RT-PCR and Immunofluorescence technique was compared for diagnosis of rabies in brain samples. Since, FAT is recommended worldwide as a standard technique for diagnosis of rabies on neural tissue, after death of animal by World Health Organization [10]. So, nested RT-PCR employed on brain samples were also compared with FAT for detecting the efficacy of these molecular techniques.

The sensitivity of various tests applied was calculated using following formula

$$
\text { Sensitivity }=\frac{\text { True positive }}{\text { True positive }+ \text { False negative }} \times 100
$$

\subsection{Analysis of nucleic acid}

\section{RESULTS AND DISCUSSION}

The 260/280 ratio of extracted RNA was in the range of 1.75-1.90 while the concentration varied from 413.17-996.40 ng/ $\mu \mathrm{l}$ and the 260/280 ratio of cDNA was in the range of 1.90-2.02 and concentration varied from $2540.30-4768.40 \mathrm{ng} / \mu \mathrm{l}$.

\subsection{Nested RT-PCR}

Amplification with primers Rab N1 and Rab N5 yielded 1477bp first round product. Nested pair of primers (Rab Nfor and Rab Nrev) used for amplification in second round yielded 762 bp product as reported by $[6,7,8]$. By nested RT-PCR, viral RNA could be diagnosed in 12/20 (60.0\%) cases (TABLE 1).

\subsection{Immunofluorescence}

Out of 20 cases, $13(65 \%)$ cases were diagnosed positive on the basis of Immunofluorescence applied on brain samples (TABLE 1).

\subsection{Sensitivity comparison of nested RT-PCR with Immunofluorescence}

Nested RT-PCR was found to be $92.85 \%$ sensitive. Earlier workers have reported sensitivity of nested RT-PCR lesser than the present study viz. 52\% [11] and 86\% [12]. However, higher sensitivity by similar approach has also been reported [13]. Diagnosis of rabies by nested RT-PCR, therefore, offers promise as an alternate diagnostic tool that could be highly significant for detection of rabies from putrefied brain samples where FAT fails to give authentic diagnosis.

\section{CONCLUSION}

So far, conventional method (Immunofluorescence) has been reported to be a reliable test for diagnosis of rabies. Several other methods have been reported by various researchers, each having its own merits and demerits. In the present study It can be concluded that the sensitivity of Nested RT-PCR is comparable with Immunofluorescence and can be used for confirmatory diagnosis of rabies. This study suggests that Nested RTPCR is a useful, specific, sensitive and better molecular approach and can be used as future diagnostic tool on samples like saliva, skin, hair follicles, urine and milk for ante-mortem diagnosis of rabies thus prevents post exposure prophylaxis and unnecessary treatment.

\section{ACKNOWLEDGEMENTS}

Authors are grateful to Dr. S N S Randhawa, Director of Research, GADVASU for providing the necessary research facilities and Director Animal Husbandry for sponsoring research scheme entitled "Development of Research-cum-Diagnostic laboratory for Rabies". 


\section{REFERENCE}

[1] T. Nagarajan, S. B. Nagendrakumar, B. Mohannasubramanian, S. Rajalakshmi, N. R. Hanumantha, R. Ramya, D. Thiagarajan and V. A. Srinivasan, Phylogenetic analysis of nucleoprotein gene of dog rabies virus isolates from Southern India, Infectious Gene Evolution, 9, 2009, 976-982.

[2] A. I. Wandeler, S. A. Nadin-Davis, R. R. Tinline and C. E. Rupprecht, Rabies epidemiology: some ecological and evolutionary perspectives, Current Topics Microbiology Immunology, 187, 1994, 297-324.

[3] F. Cliquet, J. P. Gurbuxani, H. K. Pradhan, B. Pattnaik, S. S. Patil, A. Regnault, H. Begouen, A. L. Guiot, R. Sood, P. Mahl, R. Singh, F. X. Meslin, E. Picard, M F A Aubert and J. Barrat, The safety and efficacy of the oral rabies vaccineSAG2 in Indian stray dogs, Vaccine, 25, 2007, 3409-3418.

[4] D. J. Dean and M. K. Abelseth, Fluorescent antibody tests ( $3^{\text {rd }}$ Ed.) Laboratory Techniques in Rabies, (WHO, Geneva, 1973) $73-84$.

[5] N. Tordo, D. Sacramento and H. Bourhy, The polymerase chain reaction (PCR) technique for diagnosis, typing and epidemiological studies of rabies (In: Meslin, 1995).

[6] A. Kaw, C. K. Singh, B. S. Sandhu, N. K. Sood, Ramneek, D. Deka and S. Awahan, Diagnosis of rabies in animals by Nested RT PCR, Indian Journal of Animal Sciences, 81(4), 2011, 367-369.

[7] S. A. Nadin-Davis, Polymerase chain reaction protocols for rabies virus discrimination. Journal of Virological Methods, 75, 1998, $1-8$.

[8] T. Nagaraj, P. V. Joel, A. Desai, A. Kamat, S. N. Madhusudana and V. Ravi. Ante mortem diagnosis of human rabies using saliva samples: Comparison of real time and conventional RT-PCR techniques, Journal of Clinical Virology, 36, $2006,17-23$.

[9] L. E. Smith, C. Foster, M. Hitchcock, G. Leiserowitz, K. Hall, R. Isseroff, N. Christensen and J. Kreider. Titration of HPV-11 infectivity and antibody neutralisation can be measured in vitro, J. Invest. Dermatol, 105, 1995, 438-444.

[10] A. C. Hanlon, S. J. Smith and R. G. Anderson. Article II: Laboratory diagnosis of rabies, Journal of American Veterinary Medical Association, 215, 1999, 1444-1447.

[11] D. B. Araujo, H. Langoni, M. F. Almeida, and J. Megid, Heminested reverse-transcriptase polymerase chain reaction (hnRT-PCR) as a tool for rabies virus detection in stored and decomposed samples, BMC Research Notes, 2008, 1-17.

[12] P. C. Romijn, R. V. D. Heide, C. A. M. Cattaneo, R. D. C. F. Silva and W. H. M. V. Der Poel, Study of lyssaviruses of bat origin as a source of rabies for other animal species in the state of Rio de Janeiro, Brazil, American Journal of Tropical Medicine and Hygiene, 691, 2003, 81-86.

[13] N. Kamolvarin, T. Tirawatnpong, R. Rattanasiwamoke, S. Tirawatnpong, T. Panpanich and T. Hemachudha, Diagnosis of Rabies by Polymerase Chain Reaction with Nested Primers. Journal of Infectious Diseases, 167, 1993, 207-210.

Table -1: Details of cases for postmortem diagnosis of rabies

\begin{tabular}{|c|c|c|c|c|c|}
\hline Sample No. & Species & Age & Sex & $\begin{array}{c}\text { Immuno- } \\
\text { fluorescence }\end{array}$ & $\begin{array}{c}\text { Nested } \\
\text { RT-PCR }\end{array}$ \\
\hline 1. & Buffalo & $2 \mathrm{yrs}$ & $\mathrm{F}$ & + & + \\
\hline 2. & Dog & $5 \mathrm{mths}$ & $\mathrm{F}$ & - & - \\
\hline 3. & Cow & $3 \mathrm{yrs}$ & M & + & + \\
\hline 4. & Dog & 4 yrs & M & - & - \\
\hline 5. & Buffalo & $6 \mathrm{yrs}$ & $\mathrm{F}$ & + & + \\
\hline 6. & Buffalo & $4 \mathrm{yrs}$ & $\mathrm{F}$ & - & - \\
\hline 7. & Dog & $31 / 2$ mths & M & - & - \\
\hline 8. & Buffalo & $6 \mathrm{yrs}$ & $\mathrm{F}$ & + & + \\
\hline 9. & Dog & $5 \mathrm{yrs}$ & $\mathrm{F}$ & - & - \\
\hline 10. & Cow Calf & $6 \mathrm{mths}$ & $\mathrm{F}$ & + & + \\
\hline 11. & Dog & $2^{1 / 2} \mathrm{yrs}$ & $\mathrm{F}$ & + & + \\
\hline 12. & Cow calf & $1 \mathrm{mths}$ & $\mathrm{F}$ & + & - \\
\hline 13. & Cow & $41 / 2$ yrs & $\mathrm{F}$ & + & + \\
\hline 14. & Buffalo & $8 \mathrm{yrs}$ & $\mathrm{F}$ & - & - \\
\hline 15. & Dog & $12 \mathrm{yrs}$ & M & + & + \\
\hline 16. & Dog & $1 \mathrm{yrs}$ & M & + & + \\
\hline 17. & Dog & $71 / 2 \mathrm{yrs}$ & M & + & + \\
\hline 18. & Buffalo & $7 \mathrm{yrs}$ & $\mathrm{F}$ & - & - \\
\hline 19. & Buffalo & $6 \mathrm{yrs}$ & $\mathrm{F}$ & + & + \\
\hline \multirow[t]{2}{*}{20.} & Cow & $1 \mathrm{yrs}$ & $\mathrm{F}$ & + & + \\
\hline & & $\%$ & & $13 / 20(65 \%)$ & $12 / 20(60 \%)$ \\
\hline
\end{tabular}

+ Positive, - Negative 